\title{
PAIN IN PSORIATIC ARTHRITIS AND ITS RELATION TO THE DISEASE ACTIVITY: CLINICAL AND ULTRASONOGRAPHIC STUDY
}

Abd-Elmoneim Hussein Helal, Marwa Mohamed Hassan, Eman Hassan El-Sayed*, Mohamed Mahmoud Abdel-Hamid El-Shafei**; Esraa Mohamed Mohamed Nasser Shebl Department of Physical Medicine, Rheumatology and Rehabilitation, Internal Medicine*, Radiodiagnosis**, Faculty of Medicine, Alexandria University

\section{INTRODUCTION}

Psoriatic arthritis (PsA) is a chronic, immune mediated, inflammatory musculoskeletal disease characterized by inflammation of not only articular sites major concern for patients with PsA.(2) It may be a nociceptive type of pain (caused by the inflammatory damage and tissue destruction), a neuropathic (due to augmented central chronic pain processing) or even mixed type may be present. ${ }^{(3)}$ The different pain mechanisms in PsA patients may lead to misinterpretation of the disease activity and accordingly excessive therapy. ${ }^{(4)}$

\section{AIM OF THE WORK}

To study pain in PsA patients and its relation to the disease activity by clinical and ultrasound scores.

\section{SUBJECTS AND METHODS}

Thirty patients diagnosed according to CASPAR criteria as PsA were enrolled in the current study. Patients with other neuropathic disorders (e.g. diabetic the current study. Patients with other neuropathic

neuropathy) or other rheumatic conditions were excluded.
All patients were subjected to clinical assessment of the musculoskeletal system All patients were subjected to clinical assessment of the musculoskeletal system oint Ratio (STR), Manual Tender Point Count (TPC), Widespread Pain Index (WPI) and Pain Detect Questionnaire (PDQ). The disease activity was assessed clinically by using the Disease Activity index for Psoriatic Arthritis (DAPSA), the Composite Psoriatic Disease Activity Index (CPDAI) and the Psoriatic Arthrits Disease Activity Score (PASDAS) and ultrasonographically by PsA-Son13 score.

\section{RESULTS}

Pain intensity was not significantly correlated with all clinical and US disease activity scores, but had a significant positive correlation with $\mathrm{PDQ}$, fatigue and functional measures.

(DDQ APSA.

Table 1: Correlation between pain parameters and clinical examination scores $(\mathrm{n}=30)$

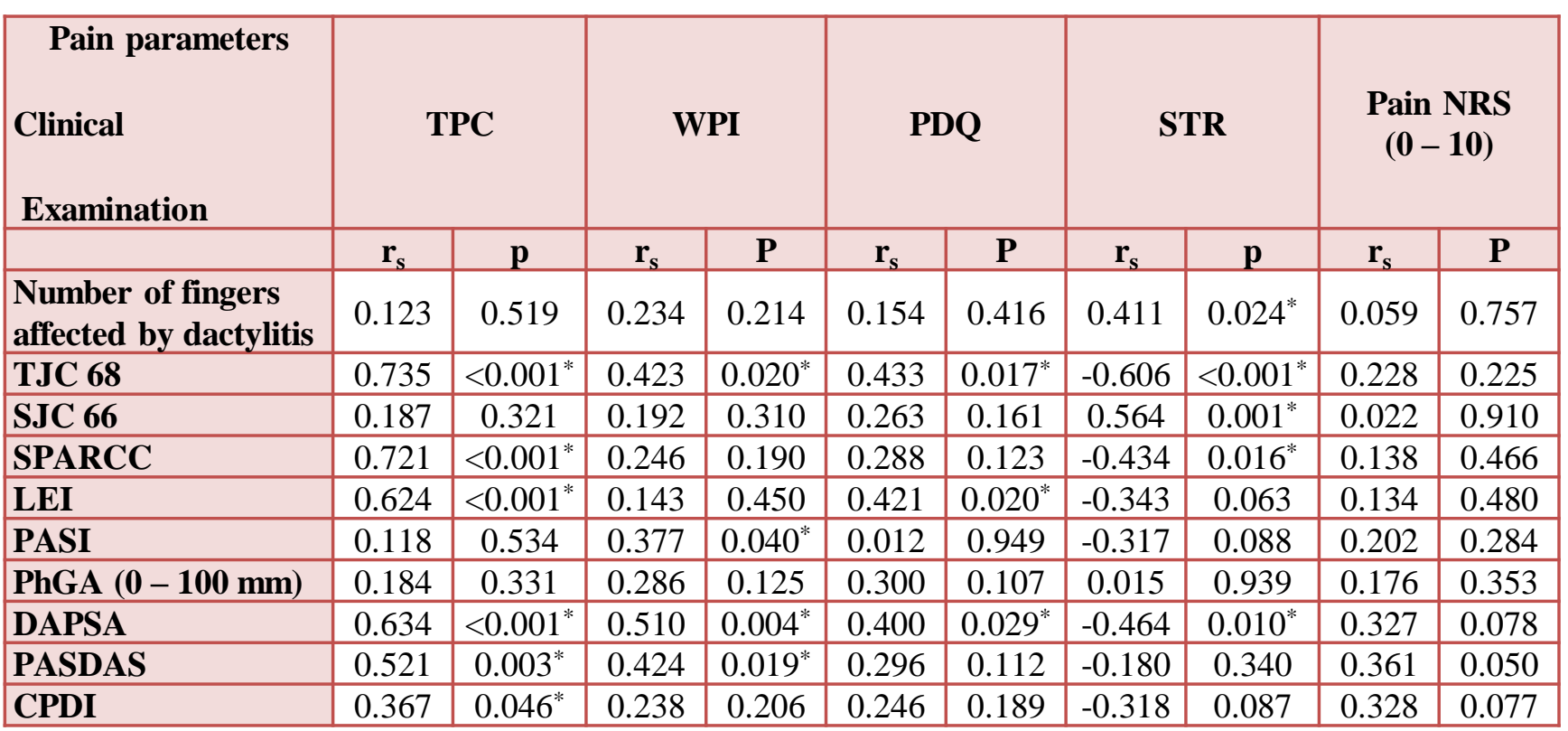

Table 2: Correlation between pain parameters with scores of disease activity $(n=30)$

\begin{tabular}{|c|c|c|c|c|c|c|c|c|c|c|}
\hline \multirow[t]{2}{*}{$\begin{array}{l}\text { Pain parameters } \\
\text { Lab. \& US findings }\end{array}$} & \multicolumn{2}{|c|}{$\begin{array}{c}\text { Manual } \\
\text { tender point } \\
\text { count }\end{array}$} & \multicolumn{2}{|c|}{ WPI } & \multicolumn{2}{|c|}{$\begin{array}{l}\text { Pain detect } \\
\text { questionnaire }\end{array}$} & \multicolumn{2}{|c|}{ STR } & \multicolumn{2}{|c|}{$\begin{array}{c}\text { Pain NRS } \\
(0-10)\end{array}$} \\
\hline & $r_{s}$ & $\mathrm{p}$ & $r_{s}$ & $\mathrm{p}$ & $r_{s}$ & $\mathrm{P}$ & $r_{s}$ & $\mathrm{p}$ & $r_{s}$ & $\mathrm{p}$ \\
\hline $\mathbf{P}(\mathrm{r}$ & 0.129 & 0.497 & 0.413 & $0.023^{*}$ & 0.119 & 0.533 & -0.149 & 0.433 & 0.037 & 0.845 \\
\hline hour 1 & -0.196 & 0.382 & -0.041 & 0.857 & 54 & 254 & 0.148 & 0.511 & 0.527 & 0.012 \\
\hline ASon13 US & 0.169 & 0.372 & 0.355 & 0.055 & 0.005 & 0.980 & 0.280 & 0.134 & -0.029 & 0.878 \\
\hline
\end{tabular}

CONCLUSION

- Pain intensity is not essentially expressing the inflammatory disease activity of PsA. Pain detect questionnaire can be a useful tool to detect neuropathic component of pain.

\section{REFERENCES}

1. Gladman DD. Clinical Features and Diagnostic Considerations in Psoriatic Arthritis. Rheum Dis Clin North Am 2015; 41(4):569-79.

2. Salaffi F, Giacobazzi G, Di Carlo M. Chronic Pain in Inflammatory Arthritis: Mechanisms, Metrology, and Emerging Targets-A Focus on the JAK-STAT Pathway. Pain Res Manag 2018; 2018:8564215.

3. Unger S, Baerwald C. Pain in Rheumatic Diseases. In: Harrison A (ed). Insights and Perspectives: InTech; 2012. 241-

4. Rifbjerg-Madsen S, Christensen AW, Christensen R, Hetland ML, Bliddal H, Kristensen LE, et al. Pain and pain mechanisms in patients with inflammatory arthritis: A Danish nationwide cross-sectional DANBIO registry survey. PLoS One 2017; 12(7):e0180014.

$$
\text { 20210Alexandria Faculty of Medicine }
$$

MEDICINE $\mid$ Sey 